\title{
Komunikasi Terapeutik pada Lansia di Graha Werdha AUSSI Kusuma Lestari, Depok
}

\author{
${ }^{1}$ Fitria Ayuningtyas, ${ }^{2}$ Witanti Prihatiningsih \\ Fakultas Ilmu Sosial dan Ilmu Politik, Universitas Pembangunan Nasional "Veteran" Jakarta

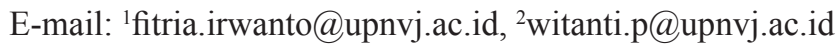

\begin{abstract}
Abstrak. Semakin tua umur seseorang, maka semakin rentan orang tersebut ihwal kesehatannya. Terdapat banyak bukti bahwa kesehatan yang optimal pada pasien lanjut usia tidak hanya bergantung kepada kebutuhan biomedis semata, namun juga bergantung kepada kondisi di sekitarnya, seperti perhatian yang lebih terhadap keadaan sosialnya, ekonominya, kulturalnya, bahkan psikologisnya dari pasien tersebut. Tujuan penelitian ini untuk mengetahui bagaimana komunikasi terapeutik yang baik bagi lansia, khususnya yang berada di Graha Werdha Aussi Kusuma Lestari Depok. Metode yang digunakan pada penelitian ini adalah metode kualitatif. Penelitian ini difokuskan pada studi kasus. Penulis juga menggunakan teknik observasi, yaitu salah satu teknik pengumpulan data dalam penelitian apa pun, termasuk penelitian kualitatif. Berdasarkan observasi langsung penulis ke Graha Werdha Aussi Kusuma Lestari, pasien lansia sangat memerlukan komunikasi yang baik dan empati serta perhatian yang "cukup" dari berbagai pihak. Banyak hambatan dari komunikasi terapeutik pada pasien lansia yang terjadi, namun dalam kasus ini yang banyak terjadi di Panti Werdha yaitu resisten. Perilaku resisten biasanya diperlihatkan pasien pada masa penyembuhan terhadap penyakit tertentu dikarenakan adanya rasa lelah, marah dan sedih terhadap penyakit yang dideritanya. Hasil dari penelitian ini merekomendasikan adanya pendekatan untuk berkomunikasi pada pasien lansia dengan baik. Oleh karena itu komunikasi terapeutik harus dapat diimplementasikan secara optimal bagi pasien lansia.
\end{abstract}

Kata kunci: komunikasi, terapeutik, pasien, lansia

\begin{abstract}
The older a person, the more vulnerable a person regarding his health. There is a lot of evidence that optimal health in elderly patients depends not only on biomedical needs but also on the conditions surrounding them, such as greater attention to their social, their economic, their cultural, and their psychological conditions of the patient. The purpose of this research is to know how the best therapeutic communication for elderly especially in Panti Werdha. The method of this research used qualitative method. This research focused on a case study. The researcher also used an observational technique as data collection techniques. This data collection technique used in some research included the qualitative research. Based on the direct observation by the researcher to Graha Werdha Aussi Kusuma Lestari, elderly patients desperately need good communication and empathy and "adequate" attention from various parties. Many obstacles to therapeutic communication in elderly patients occur, but in this case a lot of events happened in Panti Werdha due to resistant. The resistant behavior usually showed by the patient during the healing of certain diseases due to tiredness, anger, and sadness to the illness suffered by it. The result of this research indicated that there should be approach well communicate to the elderly patient. Therefore therapeutic communication should be optimally implemented for elderly patients.
\end{abstract}

Keywords: communication, therapeutic, patient, elderly 


\section{PENDAHULUAN}

Komunikasi

mempunyai

dua fungsi umum. Pertama, untuk kelangsungan hidup diri sendiri yang meliputi keselamatan fisik, meningkatkan kesadaran pribadi, menampilkan diri kita sendiri kepada orang lain dan mencapai ambisi pribadi. Kedua, untuk kelangsungan hidup masyarakat, tepatnya untuk memperbaiki hubungan sosial dan mengembangkan keberadaan suatu masyarakat tersebut (Pearson dan Nelson dalam Mulyana, 2009:5). Selain hal tersebut, menurut William I. Gorden dalam Mulyana(2009:5-6), terdapatempat fungsi komunikasi, yakni komunikasi sosial, komunikasi ekspresif, komunikasi ritual, dan komunikasi instrumental, tidak saling meniadakan (mutually exclusive). Fungsi suatu peristiwa komunikasi (communication events) tampaknya sama sekali tidak independen, melainkan juga berkaitan dengan fungsi-fungsi lainya meskipun terdapat sesuatu fungsi yang dominan.

Proses komunikasi dapat dilihat dalam dua perspektif besar, yaitu perspektif psikologis dan perspektif mekanis. Perspektif psikologis dalam proses komunikasi hendaknya memperlihatkan bahwa komunikasi adalah aktivitas psikologi sosial yang melibatkan komunikator, komunikan, isi pesan, lambang, sifat hubungan, persepsi, proses decoding dan encoding. Perspektif mekanis memperlihatkan bahwa proses komunikasi adalah aktivitas mekanik yang dilakukan oleh komunikator, yang sangat bersifat situasional dan kontekstual (Mufid, 2012:83). Manusia pada dasarnya merupakan makhluk yang suka menilai terhadap apa saja yang dilihat dan didengarnya. Kita memiliki penilaian (judgement) terhadap orang lain dan lingkungan sekitar kita. Kita akan memberikan penilaian kepada teman, keluarga, tetangga dan lingkungan sekitar kita (Morissan, 2010:19).

Semakin tua umur seseorang, maka semakin rentan seseorang tersebut mengenai kesehatannya. Terdapat banyak bukti bahwa kesehatan yang optimal pada pasien lanjut usia, atau selanjutnya penulis sebut sebagai lansia tidak hanya bergantung kepada kebutuhan biomedis semata namun juga bergantung kepada kondisi disekitarnya, seperti perhatian yang lebih terhadap keadaan sosialnya, ekonominya, kulturalnya, bahkan psikologisnya dari pasien tersebut. Walaupun seperti kita ketahui pelayanan kesehatan dari waktu ke waktu mengalami perbaikan yang cukup signifikan pada pasien lansia, namun mereka pada akhirnya tetap memerlukan komunikasi yang baik dan empati juga perhatian yang "cukup" dari berbagai pihak, terutama dari keluarganya sebagai bagian penting dalam penanganan masalah kesehatan mereka. Purwaningsih dan Karlina (2012) menyebutkan bahwa hubungan saling memberi dan menerima antara perawat dan pasien dalam pelayanan keperawatan disebut sebagai komunikasi terapeutik perawat yang merupakan komunikasi profesional perawat. Komunikasi terapeutik sangat penting dan berguna bagi pasien, karena komunikasi yang baik dapat memberikan pengertian tingkah laku pasien dan membantu pasien dalam menghadapi persoalan yang dihadapi olehnya (Utami, 2015, dalam Prasanti, 2017).

Menurut Mulyana (2005), komunikasi terapeutik termasuk komunikasi interpersonal adalah komunikasi antara orang-orang secara tatap muka yang memungkinkan setiap pesertanya menangkap reaksi orang lain sacara langsung, baik secara verbal dan nonverbal. Komunikasi antara perawat dan pasien lansia harus berjalan efektif terutama bagi pasien lansia karena mempunyai pengaruh yang besar terhadap kesehatan dari pasien lansia tersebut. Komunikasi yang baik dengan pasien adalah kunci keberhasilan untuk masalah klinis, hubungan dokter/perawat - pasien yang lebih baik dan juga berdampak bagi perawatan kesehatan pasien lansia 
tersebut. Keberhasilan komunikasi memerlukan pendekatan efektif kepada pasien, kemampuan untuk mendengarkan dan mempersilakan pasien untuk bercerita serta cakap dalam melakukan investigasi untuk mengklarifikasi dan mendapatkan informasi yang penting sangatlah diperlukan. Terkait dengan pasien lansia yang berada di Graha Werdha Aussi Kusuma Lestari, Panti Werdha, ini merupakan salah satu contoh Panti Werdha modern yang berbentuk seperti apartemen. Dikelilingi oleh taman yang ditata asri, graha werdha ini memang cukup 'wah' untuk ukuran panti umumnya. Dibangun di tanah seluas $6.000 \mathrm{~m} 2$ memiliki kapasitas kamar yang mampu menampung sekitar 60 lansia. Suasananya begitu tenang dan hawanya pun masih sejuk untuk ukuran tempat yang dekat dengan Jakarta. Graha werdha milik Yayasan AUSSI Kusuma Lestari ini juga memiliki sarana bak sebuah hotel, yang terdiri beberapa kelas kamar: VVIP, VIP, dan standard room. Untuk pemeriksaan kesehatan, mereka memiliki sarana fisioterapi dan juga bekerja sama dengan RS Puri Cinere. "Bahkan seminggu sekali kami mendatangkan hair stylist kalau ada yang mau potong atau nge-blow rambut," ujar salah seorang pengurusnya. Maka, tak heran jika mereka mematok biaya yang tidak murah bagi penghuninya, antara Rp 2.000.000 - 4.000.000 per bulan. Karenanya yang tinggal di sana kebanyakan berasal dari kalangan menengah ke atas (Kusuma, 2017).

Kultur yang terjadi di Indonesia sangat tidak menyetujui bahwa pasien lansia harus dititipkan di panti werdha, kultur di Indonesia mendukung penuh pasien lansia tinggal sendiri atau tinggal bersama keluarganya, padahal dengan demikian jika kondisi tidak memungkinkan akan menimbulkan berbagai macam permasalahan yang lebih kompleks dan rumit. Banyak alasan anak menitipkan orangtuanya ke panti werdha, seperti yang penulis kutip dalam
Djaman (2017), psikolog yang peduli pada masalah-masalah lansia, meluruskan pandangan itu. Dijelaskannya, hanya ada dua tempat penampungan lansia, yaitu panti sosial (dari pemerintah) dan panti jompo berbayar. Lansia yang masuk ke panti sosial adalah mereka yang telantar atau diketahui tidak punya keluarga. Panti sosial yang aktif berperan memasukkan lansia-lansia telantar ini. Sedangkan bila lansia berada di panti jompo berbayar - atau bahkan sekadar day care lansia, jatuhnya bukan penelantaran atau yang seperti dipikirkan banyak orang, bentuk "membuang" orangtua. "Ketika seorang lansia masuk dan tinggal di penitipan, hampir pasti disertai keinginan lansia itu sendiri," ungkap Evita.Tentu ada kesepakatan-kesepakatan yang sudah dibicarakan dan disetujui antara pihak orangtua yang sudah lansia ini dan keluarga atau anak-anaknya.

\section{Pasien Lansia}

Pasien adalah setiap orang yang melakukan konsultasi masalah kesehatannya untuk memperoleh pelayanan kesehatan yang diperlukan, baik secara langsung maupun tidak langsung di rumah sakit (Undang-undang Nomor 44 Tahun 2009 tentang Rumah Sakit). Orang lanjut usia (lansia) pada umumnya menderita lebih dari satu penyakit. Hal ini pun membuat mereka harus mendatangi sejumlah dokter spesialis untuk berobat (Maharani, 2014). Pada kenyataannya, pasien lansia berbeda dengan pasien kebanyakan. Pasien lansia mempunyai cara khusus dalam perawatannya mengingat usianya sudah tidak muda lagi dan kebanyakan dari pasien lansia mempunyai penyakit yang kompleks dan atau beberapa penyakit sekaligus. Kegiatan ini, menurut Depkes (1993:1b), untuk memberikan bantuan, bimbingan, pengawasan, perlindungan, dan pertolongan kepada lanjut usia secara individu maupun kelompok, seperti di rumah atau lingkungan keluarga, puskesmas, yang diberikan 
perawat. Untuk asuhan keperawatan yang masih dapat dilakukan anggota keluarga atau petugas sosial yang bukan tenaga keperawatan, diperlukan latihan sebelumnya atau bimbingan langsung pada waktu tenaga keperawatan melakukan asuhan keperawatan di rumah atau panti. Adapun asuhan keperawatan dasar yang diberikan, disesuaikan pada kelompok lanjut usia, apakah lanjut usia aktif atau pasif, antara lain, untuk lanjut usia yang masih aktif, asuhan keperawatan dapat berupa dukungan tentang personal hygiene, kebersihan lingkungan serta makanan yang sesuai dan kesegaran jasmani; untuk lanjut usia yang telah mengalami pasif, yang tergantung pada orang lain. Hal yang perlu diperhatikan dalam memberikan asuhan keperawatan pada lanjut usia pasif pada dasarnya sama sama seperti pada lanjut usia aktif, dengan bantuan penuh oleh anggota keluarga atau petugas. Khususnya bagi yang lumpuh, perlu dicegah agar tidak terjadi dekubitus.Lanjut usia mempunyai potensi besar untuk terjadi dekubitus karena perubahan kulit berkaitan dengan bertambahnya usia dalam Perwari (2015).

\section{Komunikasi Terapeutik}

Dalam Prasanti (2017) komunikasi terapeutik adalah komunikasi yang direncanakan secara sadar, bertujuan dan kegiatannyadipusatkanuntukkesembuhan pasien. Dalam dunia kesehatan, banyak kegiatan komunikasi terapeutik yang terjadi. Menurut Heri Purwanto, komunikasi terapeutik adalah komunikasi yang direncanakan secara sadar dan bertujuan, kegiatannya difokuskan untuk kesembuhan pasien, dan merupakan komunikasi profesional yang mengarah pada tujuan untuk penyembuhan pasien (dalam Mundakir, 2006). Komunikasi terapeutik meningkatkan pemahaman dan membantu terbentuknya hubungan yang konstruktif di antara perawat dengan klien. Tidak seperti komunikasi sosial, komunikasi terapeutik mempunyai tujuan untuk membantu klien mencapai suatu tujuan dalam asuhan keperawatan. Stuart dan Sundeen dalam Taufik (2010:45) menjelaskan bahwa dalam prosesnya komunikasi terapeutik terbagi menjadi empat tahapan, yaitu tahap persiapan atau tahap pra-interaksi, tahap perkenalan atau orientasi, tahap kerja, dan tahap terminasi. Adapun penjelasan dari masingmasing tahapan tersebut sebagai berikut:

(1) Tahap pra-interaksi, pada tahap prainteraksi, perawat/dokter sebagai komunikator yang melaksanakan komunikasi terapeutik mempersiapkan dirinya untuk bertemu dengan klien atau pasien. Sebelum bertemu pasien, perawat/ dokter haruslah mengetahui beberapa informasi mengenai pasien, baik berupa nama, umur, jenis kelamin, keluhan penyakit, dan sebagainya. Apabila perawat/ dokter telah dapat mempersiapkan diri dengan baik sebelum bertemu dengan pasien, maka ia akan bisa menyesuaikan cara yang paling tepat dalam menyampaikan komunikasi terapeutik kepada pasien, sehingga pasien dapat dengan nyaman berkonsultasi dengan petugas/dokter.

(2) Tahap perkenalan atau tahap orientasi pada tahap ini antara petugas/dokter dan pasien terjadi kontak dan pada tahap ini penampilan fisik begitu penting karena dimensi fisik paling terbuka untuk diamati. Kualitas-kualitas lain seperti sifat bersahabat kehangatan, keterbukaan dan dinamisme juga terungkap.

(3) Tahap kerja atau sering disebut sebagai tahap lanjutan adalah tahap pengenalan lebih jauh, dilakukan untuk meningkatkan sikap penerimaan satu sama lain untuk mengatasi kecemasan, melanjutkan pengkajian dan evaluasi masalah yang ada, pada tahap ini termasuk pada tahap persahabatan yang menghendaki agar kedua pihak 
harus merasa mempunyai kedudukan yang sama, dalam artian ada keseimbangan dan kesejajaran kedudukan. Secara psikologis komunikasi yang bersifat terapeutik akan membuat pasien lebih tenang, dan tidak gelisah.

(4) Tahapan terminasi, pada tahap ini terjadi pengikatan antar pribadi yang lebih jauh, merupakan fase persiapan mental untuk membuat perencanaan tentang kesimpulan perawatan yang didapat dan mempertahankan batas hubungan yang ditentukan, yang diukur, antara lain, mengantisipasi masalah yang akan timbul karena pada tahap ini merupakan tahap persiapan mental atas rencana pengobatan, melakukan peningkatan komunikasi untuk mengurangi ketergantungan pasien pada petugas/dokter. Terminasi merupakan akhir dari setiap pertemuan antara petugas dengan klien. Bahwa tahap terminasi dibagi dua, yaitu terminasi sementara dan terminasi akhir. Terminasi sementara adalah akhir dari setiap pertemuan, pada terminasi ini klien akan bertemu kembali pada waktu yang telah ditentukan, sedangkan terminasi akhir terjadi jika klien selesai menjalani pengobatannya.

\section{METODE}

Metode yang digunakan pada penelitian ini adalah metode kualitatif. Menurut Denzin dan Lincoln (1998:8) dalam Ahmadi (2014:14-15) kata kualitatif menyatakan penekanan pada proses dan makna yang tidak diuji atau diukur dengan setepat-tepatnya, dalam istilah-istilah kuantitas, jumlah, intensitas atau frekuensi. Para peneliti kualitatif menekankan sifat realitas yang dikonstruk secara sosial, hubungan yang intim antara peneliti dan apa yang distudi dan kendalakendala situasional yang membentuk inkuiri. Denzin dan Lincoln (1994) dalam Creswell (1998:15) mengemukakan bahwa penelitian kualitatif adalah multimetode dalam fokus termasuk pendekatan interpretif dan naturalistik terhadap pokok permasalahannya. Ini berarti para penulis kualitatif mengkaji segala sesuatu dalam latar alamiahnya, berusaha untuk memahami atau menginterpretasi fenomena dalam hal makna-makna yang orang-orang berikan pada fenomena tersebut. Penelitian kualitatif mencakup penggunaan dan pengumpulan beragam material empiris yang digunakan -studi kasus, pengalaman personal, introspektif, kisah hidup dan teks wawancara, observasi, sejarah, interaksional dan teks visualyang mendeskripsikan momen-momen rutin dan problematik serta makna dalam kehidupan individual dalam Ahmadi (2014:14-15).

Adapun pada penelitian ini difokuskan pada studi kasus. Penelitian lapangan tidak mempunyai desain penelitian yang dipaketkan sebelumnya. Lebih dari itu, metodemetode pengumpulan data yang spesifik, prosedur sampling, dan pola-pola analisis yang digunakan untuk menciptakan desain pertanyaan-spesifik yang unik yang mencakup seluruh proses penelitian.

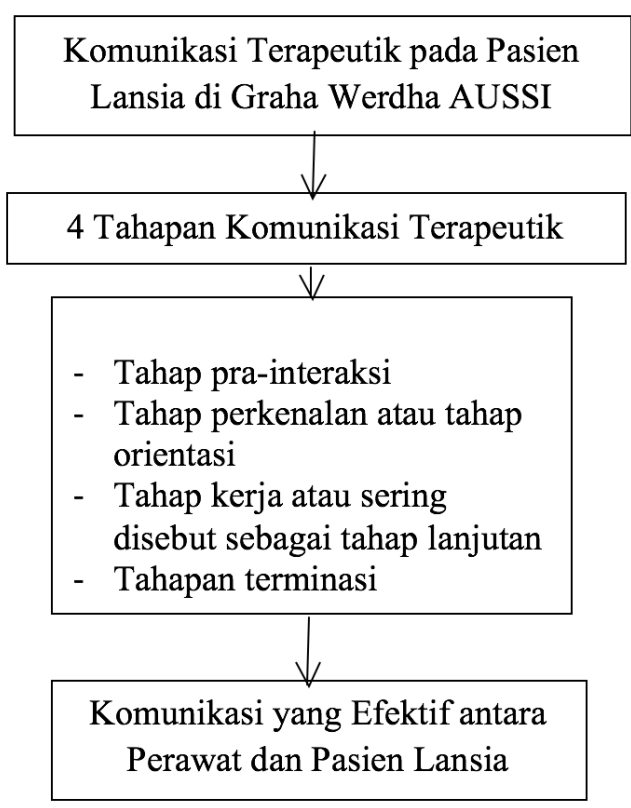

GAMBAR 1. Alur Pemikiran 
Desain kualitatif atau lapangan ini mengambil bentuk, baik suatu studi kasus atau studi topikal (Crabtree \& Miller, 1998:5). Studi kasus adalah suatu kajian rinci tentang satu latar atau subjek tunggal atau satu tempat penyimpanan dokumen atau suatu peristiwa tertentu (Bogdan \& Biklen, 1998:54). Definisi lain mengetengahkan bahwa studi kasus adalah eksaminasi sebagian besar atau seluruh aspek-aspek potensial dari unit atau kasus khusus yang dibatasi secara jelas (atau serangkaian kasus) (Ahmadi, 2014:15).

Dalam penelitian ini pun, penulis menggunakan teknik observasi di mana observasi merupakan salah satu teknik pengumpulan data dalam penelitian apa pun, termasuk penelitian kualitatif dan digunakan untuk memperoleh informasi atau data sebagaimana tujuan penelitian. Dalam penelitian kualitatif, ada beberapa tipe observasi sebagaimana akan dijabarkan dalam uraian berikut. Istilah observasi, dimana sebagian besar ilmuwan sosial memaknai observasi partisipan, telah menjadi sinonim dengan penelitian lapangan (Williamson, Karp, dan Dalpin, 1977:199), kerja lapangan atau observasi tidak terkontrol, observasi partisipan dan non partisipan (Guban dan Lincoln, 1981:189) dalam Ahmadi (2014:161). Tujuan data observasi adalah untuk mendeskripsikan latar yang diobservasi; kegiatan-kegiatan yang terjadi di latar itu; orang-orang yang berpartisipasi dalam kegiatan-kegiatan; makna latar; kegiatan-kegiatan dan partisipasi mereka dalam orang-orangnya menurut Patton (1980:124) dalam Ahmadi (2014:162).

Miles dan Huberman mengemukakan bahwa aktivitas dalam analisis data kualitatif dilakukan secara interaktif dan berlangsung secara terusmenerus sampai tuntas, sehingga datanya sudah jenuh. Aktivitas dalam analisis data, yaitu data reduction, data display, dan conclusion drawing verification dalam Moleong (2010:246). Langkah analisis data model interaktif ditunjukkan pada Gambar 2.

Pada bagan tersebut terlihat adanya ketiga kegiatan yang saling terkait dan merupakan rangkaian yang tidak berdiri sendiri. Penyajian data selain berasal dari hasil reduksi, perlu juga dilihat kembali dalam proses pengumpulan data untuk memastikan bahwa tidak ada data penting yang tertinggal. Demikian jika dalam verifikasi ternyata ada kesimpulan yang masih meragukan dan belum disepakati kebenaran maknanya, maka kembali pada proses pengumpulan data. Tindakan memvalidasi data sangat penting dalam penarikan kesimpulan.

Dalam penelitian ini, penarikan kesimpulan dilakukan setelah data yang diperoleh di lapangan telah terkumpul, data primer maupun data sekunder yang diperoleh melalui observasi,

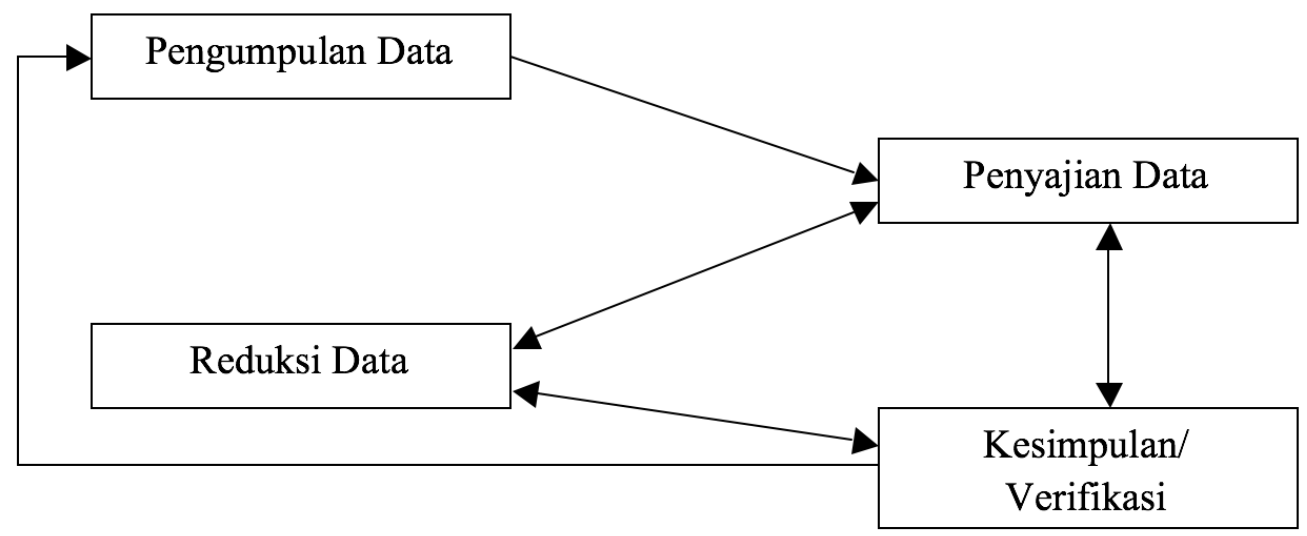

GAMBAR 2. Model Interaktif Miles dan Huberman

Sumber: Moleong (2010:246) 
wawancara, maupun dokumen yang diperoleh di lapangan, disimpulkan setelah dilakukan pemilihan antara data yang penting dan yang tidak penting sehingga penarikan kesimpulan dalam penelitian ini menghasilkan data yang valid. Jika masih ada kekurangan akan kebenaran data tersebut, peneliti kembali melakukan pengumpulan data baik dengan observasi maupun wawancara dengan informan yang dianggap berkompeten dengan penelitian ini dan akan memberikan jawaban yang jujur, sehingga menghasilkan data-data yang akurat pada saat dilakukan verifikasi.

\section{HASIL DAN PEMBAHASAN}

Menurut WHO dalam Depkes (2015), batasan umur seseorang yang tergolong lanjut usia (lansia) adalah sebagai berikut: Middle age: 45 - 59 tahun, Elderly (lansia): $60-70$ tahun, Old (lansia tua): 75 - 90 tahun, Very Old (lansia sangat tua): > 90 tahun. Berdasarkan penjelasan dari pendahuluan di atas sebelumnya dan juga berdasarkan observasi langsung penulis ke Graha Werdha Aussi Kusuma Lestari yang beralamatkan di Jalan Bandung No. 25, Bukit Cinere Indah, Kota Depok, Jawa Barat, kondisi para penghuni di Graha Werdha Aussi Kusuma Lestari rata-rata berusia Elderly (lansia): 60 - 70 tahun dan Old (lansia tua): 75 - 90 tahun. Tidak ditemukan oleh penulis untuk Middle age: 45 - 59 tahun dan Very Old (lansia sangat tua): $>90$ tahun di Graha Werdha Aussi Kusuma Lestari. Hal tersebut dikarenakan Middle age: 45 59 tahun rata-rata masih produktif dan masih bekerja di kantor atau berbisnis, kondisipun masih sangat stabil walaupun terkadang sudah mengalami beberapa keluhan seperti gula darah tinggi, tekanan darah tinggi, sering merasa lelah, dan asam urat meningkat. Sedangkan untuk usia Very Old (lansia sangat tua): $>90$ tahun mengapa tidak dapat ditemukan di Graha Werdha tersebut dikarenakan berdasarkan hasil penelusuran penulis dari Central Intelligence Agency (2010) tentang the world factbook yang menyebutkan bahwa usia harapan hidup orang Indonesia rata-rata adalah 70 sampai dengan maksimal 76 tahun. Namun saat ini, rata-rata penghuni yang ada di Graha Werdha Aussi Kusuma Lestari, yaitu berusia 60 sampai dengan 90 tahun.

Berdasarkan luas bangunan dan juga jumlah kamar, Graha Werdha ini dapat menampung sebanyak 60 lansia. Namun, saat penulis melakukan kunjungan ke Graha Werdha tersebut yang ada di sana saat ini hanya \pm 55 lansia. Penulis pun membuat rangkuman pada Tabel 1 di bawah ini berdasarkan hasil observasi dan juga berdasarkan hasil tanya-jawab penulis ke bagian administrasi dari Graha Werdha ini. Bagian adminstrasi tersebut tidak dapat menyebutkan dengan pasti jumlah dari masing-masing kategori usia dikarenakan penulis berkunjung ke Graha Werdha tersebut pada hari Sabtu, di mana bank data mengenai biodata lengkap dari penghuni Graha Werdha ini hanya dapat diakses pada hari kerja saja, yaitu Senin sampai dengan Jumat dan sifatnya sangat rahasia. Untuk dapat menjadi "penghuni" di Graha Werdha ini, sebelumnya lansia harus berusia minimal 60 tahun dan juga harus mengikuti check up kesehatan oleh tim dokter yang bekerjasama dengan Graha Werdha AUSSI serta wawancara dengan lansia dan pihak keluarga. Pihak keluarga pun harus mengisi form lengkap sebagai penanggung jawab dari lansia tersebut jika sewaktu-waktu terjadi sesuatu ke lansia tersebut. Para lansia pun harus didampingi penuh oleh masingmasing perawat/suster, perawat/suster tersebut dapat dicarikan oleh Graha Werdha atau dicarikan sendiri oleh pihak keluarga. Adapun untuk biaya sewa bagi perawat/suster tersebut di Graha Werdha ini masing-masing keluarga dari lansia dikenakan tarif Rp. 2.000.000 per bulan di luar dari gaji bulanan dan makan serta kebutuhan lainnya dari perawat/ suster tersebut, sehingga penulis dapat 
TABEL 1. Kategori Lansia berdasarkan Kategori Batasan Usia dari WHO

\begin{tabular}{|c|c|c|}
\hline Kategori Usia & Elderly (Lansia): 60 - 70 tahun & $\begin{array}{l}\text { Old (Lansia Tua): } 75-90 \\
\text { tahun }\end{array}$ \\
\hline Kemampuan & Mandiri & Cukup Mandiri \\
\hline Aktivitas & $\begin{array}{l}\text { Masih memiliki insiatif sendiri } \\
\text { dan kelompok, masih belum } \\
\text { membutuhkan perawat, mampu } \\
\text { bersosialisasi dengan baik. }\end{array}$ & $\begin{array}{l}\text { Membutuhkan perawat, } \\
\text { inisiatif sudah terbatas, } \\
\text { membutuhkan terapi } \\
\text { kesehatan dikarenakan } \\
\text { kesehatan sudah mulai kurang } \\
\text { baik. }\end{array}$ \\
\hline Jumlah & \pm 40 lansia & \pm 15 lansia \\
\hline
\end{tabular}

Sumber: Observasi penulis di lapangan

menyimpulkan untuk dapat menjadi penghuni di Graha Werdha ini harus berusia minimal 60 tahun, berkondisi sehat jasmani dan rohani serta mampu secara finansial. Pada Tabel 1 diuraikan data yang penulis dapat berdasarkan hasil lapangan.

Pasien lansia sangat memerlukan komunikasi yang baik dan empati juga perhatian yang "cukup" dari berbagai pihak, terutama dari keluarganya sebagai bagian penting dalam penanganan masalah kesehatan mereka. Namun, dengan berkembangnya zaman dan semakin tingginya kebutuhan hidup sehari-hari maka orang-orang kini sibuk untuk bekerja mencari nafkah. Berangkat ke tempat kerja sebelum subuh dan tiba di rumah saat malam hari dikarenakan macetnya jalanan di area sekitar Jabodetabek (Jakarta, Bogor, Depok, Tangerang, dan Bekasi). Hal tersebut ternyata menjadi alasan utama, sebagian orang yang menitipkan orangtuanya yang telah lansia ke Panti Werdha dan tidak semata-mata untuk "membuangnya," melainkan ingin memberikan kenyamanan dan keamanan mengingat jika ditinggal sendiri di rumah memiliki risiko yang tidak sedikit. Graha Werdha Aussi Kusuma Lestari, di mana AUSSI merupakan kepanjangan dari Alumnarum Ursulae Sanctae Societas Internasionalis merupakan salah satu panti werdha yang berada di Cinere (salah satu area yang cukup elit di kota Depok), cukup dekat ke
Jakarta merupakan salah satu contoh panti werdha modern yang berbentuk seperti apartemen. Berdirinya Graha Werdha ini berawal dari kepedulian para anggota Alumnarum Ursulae Sanctae Societas Internasionalis (AUSSI) yang merupakan organisasi para lulusan sekolah Ursulin, pada tahun 1990 timbul gagasan mendirikan hunian nyaman untuk para lansia. Pada tanggal 16 November 1996 akhirnya resmi dibuka Graha Werdha ini. Fasilitas ini dikelola penuh oleh para anggota Alumnarum Ursulae Sanctae Societas Internasionalis (AUSSI) secara non-profit di bawah payung Yayansan AUSSI Kusuma Lestari.

Bangunan Graha Werdha ini dikelilingi taman yang ditata asri, udara yang sejuk dan juga pemandangan yang cukup indah karena posisi tempat ini berada di perbukitan. Graha werdha ini dikenal cukup 'wah' untuk ukuran panti werdha umumnya. Dibangun di tanah seluas $6.000 \mathrm{~m}^{2}$, memiliki kapasitas kamar yang mampu menampung sekitar 60 lansia. Suasananya begitu tenang dan hawanya pun masih sejuk untuk ukuran tempat yang dekat dengan Jakarta. Graha Werdha ini dilengkapi dengan satpam yang standby selama 24 jam, mobil ambulan dan juga fasilitas lainnya seperti televisi agar lansia tidak bosan. Pada pagi hari para lansia diajak untuk olahraga atau setidaknya menggerakkan badannya bagi yang sudah tidak mampu berolahraga di halaman depan panti, di halaman depan 
panti cukup luas dan juga memiliki parkiran yang dapat menampung banyak kendaraan.

Banyak hambatan dari komunikasi terapeutik pada pasien lansia yang terjadi. Namun, dalam kasus ini yang banyak terjadi di panti werdha tersebut yaitu resisten. Resisten merupakan upaya klien untuk tetap tidak menyadari aspek penyebab ansietas yang dialaminya. Resisten merupakan ketidaksediaan pasien untuk berubah, ketika kebutuhan untuk berubah dirasakan harus segera dilaksanakan demi kesembuhan atau kesehatan si pasien namun pasien tidak bersedia. Perilaku resisten biasanya diperlihatkan oleh pasien pada masa penyembuhan terhadap penyakit tertentu dikarenakan adanya rasa lelah, rasa marah dan rasa sedih terhadap penyakit yang diderita olehnya.

Berdasarkan informasi yang penulis dapat, banyak para lansia jika mengeluhkan sakit tidak ingin diobati atau dibawa ke dokter/rumah sakit terdekat. Usaha untuk meyakinkan pasien lansia untuk berobat ke dokter/ rumah sakit bukanlah sesuatu hal yang mudah. Seringkali jika ingin dibawa ke dokter/rumah sakit, pasien tersebut menolak dengan berbagai alasan. Ia menyampaikan keberatannya jika dibawa ke dokter/rumah sakit. Namun berdasarkan observasi penulis setelah melakukan tanya-jawab dan melakukan obrolan santai dengan beberapa lansia ( 2 orang dalam kondisi sakit dan 3 orang dalam kondisi sebelum sakit atau dapat dikatakan dalam kondisi sehat) di graha tersebut hal sebenarnya dikarenakan sebuah ketakutan. Pasien lansia mencemaskan kalau dirinya dibawa ke dokter/rumah sakit maka harus dioperasi/ dibedah dan lain sebagainya. Dengan adanya masalah tersebut, maka harus ada pendekatan untuk berkomunikasi pada pasien lansia dengan baik. Oleh karena itu, komunikasi terapeutik harus dapat diimplementasikan secara optimal bagi pasien lansia. Adapun komunikasi terapeutik merupakan komunikasi yang direncanakan secara sadar, bertujuan dan dipusatkan untuk kesembuhan pasien.

Komunikasi terapeutik mengarah pada bentuk komunikasi interpersonal. Pace (1979) dalam Cangara (2012:32) mengemukakan bahwa komunikasi antarpribadi atau interpersonal communication merupakan proses komunikasi yang berlangsung antara dua orang atau lebih secara tatap muka di mana pengirim dapat menyampaikan pesan secara langsung dan penerima pesan dapat menerima dan menanggapi secara langsung. Komunikasi interpersonal merupakan komunikasi yang pesannya dikemas dalam bentuk verbal atau nonverbal, seperti komunikasi pada umumnya komunikasi interpersonal selalu mencakup dua unsur pokok, yaitu isi pesan dan bagaimana isi pesan dikatakan atau dilakukan secara verbal atau nonverbal. Dua unsur tersebut sebaiknya diperhatikan dan dilakukan berdasarkan pertimbangan situasi, kondisi, dan keadaan penerima pesan. Selain hal tersebut, komunikasi sosial sangat mendukung bagi komunikasi terapeutik bagi pasien lansia.

Mulyana

(2009:5-6),

menyebutkan fungsi pertama dari fungsi komunikasi yang baik yaitu komunikasi sosial. Fungsi komunikasi sebagai komunikasi sosial setidaknya mengisyaratkan bahwa komunikasi penting untuk membangun konsep-konsep diri, aktualisasi diri, untuk kelangsungan hidup, untuk kebahagiaan, terhindar dari tekanan dan ketegangan antara lain lewat komunikasi yang menghibur dan memupuk hubungan dengan orang lain. Fungsi komunikasi sosial ini harus dapat diterapkan dengan baik di lingkungan panti werdha mengingat semakin tuanya seseorang banyak hal yang telah berubah atau bahkan tidak berfungsi dengan baik.

Ketika berkomunikasi dengan pasien lansia dengan pendengaran yang berkurang, tataplah pasien sehingga pasien dapat membaca bibir dan menggunakan 
isyarat mata. Meminimalkan kebisingan, dan berbicara pelan, jelas, dan dalam nada yang normal. Berteriak akan menghambat komunikasi, mengubah nada berfrekuensi tinggi, dan mempersulit pasien untuk memahami kata-kata Anda. Jika suara Anda melengking, meredam lengkingan ketika Anda berbicara dapat membantu pasien untuk mendengar Anda dengan lebih baik. Ketika memberikan instruksi untuk medikasi, tes, atau pengobatan, hindarkan untuk bertanya kepada pasien apakah dia mengerti atau tidak. Orang dengan gangguan pendengaran mungkin akan menjawab "ya" tanpa menyadari bahwa mereka belum mendengar apapun atau salah memahami beberapa informasi. Pendekatan yang lebih baik untuk mengecek pemahaman pasien adalah dengan meminta pasien untuk mengulang instruksi.

Ketika berkomunikasi dengan pasien dengan gangguan penglihatan, lingkungan dapat diperbaiki dengan memperbanyak pencahayaan, menggunakan warna-warna kontras untuk membuat objek lebih jelas dan menggunakan huruf yang besar serta berwarna kontras untuk setiap tanda. Setiap bahan dengan tulisan harus dicetak paling tidak dengan huruf berukuran 14 diatas kertas berwarna. Ketika membahas rencana pengobatan, ingatlah masalah keamanan potensial yaitu gangguan penglihatan.

\section{Pendekatan Keperawatan Lanjut Usia}

Berdasarkan kondisi di lapangan, nyatanya perawatan bagi lanjut usia mempunyai pendekatan-pendekatan sebagai berikut:

\section{Pendekatan Fisik}

Perawatan yang memperhatikan kesehatan obyektif, kebutuhan, kejadiankejadian yang dialami pasien lanjut usia semasa hidupnya, perubahan fisik pada organ tubuh, tingkat kesehatan yang masih bisa dicapai dan dikembangkan, dan penyakit yang dapat dicegah atau ditekan progresivitasnya. Perawatan fisik secara umum bagi pasien lanjut usia dapat dibagi atas dua bagian, yakni pasien lanjut usia yang masih aktif, yang keadaan fisiknya masih mampu bergerak tanpa bantuan orang lain sehingga untuk kebutuhan sehari-hari masih mampu melakukan sendiri; pasien lanjut usia yang pasif atau tidak dapat bangun, yang keadaan fisiknya mengalami kelumpuhan atau sakit. Perawat harus mengetahui dasar perawatan pasien lanjut usia ini terutama tentang hal-hal yang berhubungan dengan keberhasilan perorangan untuk mempertahankan kesehatannya. Kebersihan perorangan (personal hygiene) sangat penting dalam usaha mencegah timbulnya peradangan, mengingat sumber infeksi dapat timbul bila keberihan kurang mendapat perhatian.

\section{Pendekatan Psikis}

Perawatharus mempunyai peranan penting untuk mengadakan pendekatan edukatif pada lanjut usia, perawat dapat berperan sebagai supporter, interpreter terhadap segala sesuatu yang asing, dan sebagai sahabat yang akrab. Perawat hendaknya memiliki kesabaran dan ketelitian dalam memberikan kesempatan dan waktu yang cukup banyak untuk menerima berbagai bentuk keluhan agar para lanjut usia merasa puas. Perawat harus selalu memegang prinsip "Triple S", yaitu sabar, simpatik, dan service.

Bila perawat ingin mengubah tingkah laku dan pandangan mereka terhadap kesehatan, perawat bisa melakukannya secara perlahan dan bertahap, perawat harus dapat mendukung mental mereka kearah pemuasan pribadi sehingga seluruh pengalaman yang dilaluinya tidak menambah beban, bila perlu diusahakan agar dimasa lanjut usia ini mereka dapat merasa puas dan bahagia.

\section{Pendekatan Sosial}

Mengadakan diskusi, tukar 
pikiran, dan bercerita merupakan salah satu upaya perawat dalam pendekatan sosial. Memberi kesempatan untuk berkumpul bersama dengan sesama klien lanjut usia berarti menciptakan sosialisasi mereka. Pendekatan sosial ini merupakan suatu pegangan bagi perawat bahwa orang yang dihadapinya adalah makhluk sosial yang membutuhkan orang lain. Dalam pelaksanaannya, perawat dapat menciptakan hubungan sosial antara lanjut usia dan lanjut usia maupun lanjut usia dan perawat sendiri.

Perawat memberikan kesempatan yang seluas-luasnya kepada para lajut usia untuk mengadakan komunikasi dan melakukan rekreasi, misalnya jalan pagi, menonton film, atau hiburan-hiburan lain misalnya bermain dengan anakanak yang memiliki keceriaan luar biasa seperti yang dilakukan oleh Sekolah Cita Persada, Cinere, Depok pada tanggal 30 Maret 2017 lalu dengan mendatangi Graha Werdha AUSSI Kusuma Lestari.

Para lanjut usia perlu dirangsang untuk mengetahui dunia luar, seperti menonton tv, mendengar radio, atau membaca majalah dan surat kabar. Dapat disadari bahwa pendekatan komunikasi dalam perawatan tidak kalah pentingnya dengan upaya pengobatan medis dalam proses penyembuhan atau ketenangan para pasien lanjut usia.

\section{Pendekatan Spiritual}

Perawat harus bisa memberikan ketenangan dan kepuasan batin dalam hubungannya dengan Tuhan atau agama yang dianutnya, terutama bila pasien lanjut usia dalam keadaan sakit atau mendekati kematian.

Sehubungan dengan pendekatan spiritual bagi pasien lanjut usia yang menghadapi kematian, Dr. Tony Setyabudhi mengemukakan bahwa maut seringkali menggugah rasa takut. Rasa takut semacam ini didasari oleh berbagai macam faktor, seperti tidakpastian akan pengalaman selanjutnya, adanya rasa sakit atau penderitaan yang sering menyertainya, kegelisahan untuk tidak kumpul lagi dengan keluarga atau lingkungan sekitarnya.

\section{Komunikasi Terapeutik pada Lansia}

Peranan perawat sangat besar sekali bagi lansia yang berada di Graha Werdha AUSSI Kusuma Lestari, Depok. Adapun 4 (empat) keharusan yang harus dimiliki oleh seorang perawat, yaitu pengetahuan, ketulusan, semangat dan praktik. Dalam usaha berkomunikasi dengan baik, seorang perawat harus mempunyai pengetahuan yang cukup, sehingga memudahkan dalam melaksanakan tugasnya setiap hari. Untuk ketulusan, jika seseorang telah memutuskan sebagai perawat harus dapat dipastikan mempunyai ketulusan yang mendalam bagi para pasiennya siapa pun itu. Semangat serta pantang menyerah harus selalu dikobarkan setiap harinya agar para pasiennya selalu ikut bersemangat pada akhirnya terutama bagi para pasien lansia yang terkadang suka merasa dirinya "terbuang" dan "sakit karena tua". Sedangkan untuk praktiknya, seorang perawat harus dapat berbicara komunikatif dengan para pasiennya, sehingga tidak saja hanya jago dalam teori namun praktiknya pun harus bisa melakukan dengan baik dan benar.

Terkait dengan penjelasan di atas, Stuart dan Sundeen dalam Taufik (2010:45) menjelaskan bahwa dalam prosesnya komunikasi terapeutik terbagi menjadi empat tahapan, yaitu tahap persiapan atau tahap pra-interaksi, tahap perkenalan atau orientasi, tahap kerja, dan tahap terminasi.

(1) Tahap pra-interaksi, pada tahap pra-interaksi, perawat sebagai komunikator yang melaksanakan komunikasi terapeutik mempersiapkan dirinya untuk bertemu dengan klien atau pasien lansia. Sebelum bertemu pasien, perawat haruslah mengetahui beberapa informasi mengenai pasien, baik berupa nama, umur, 


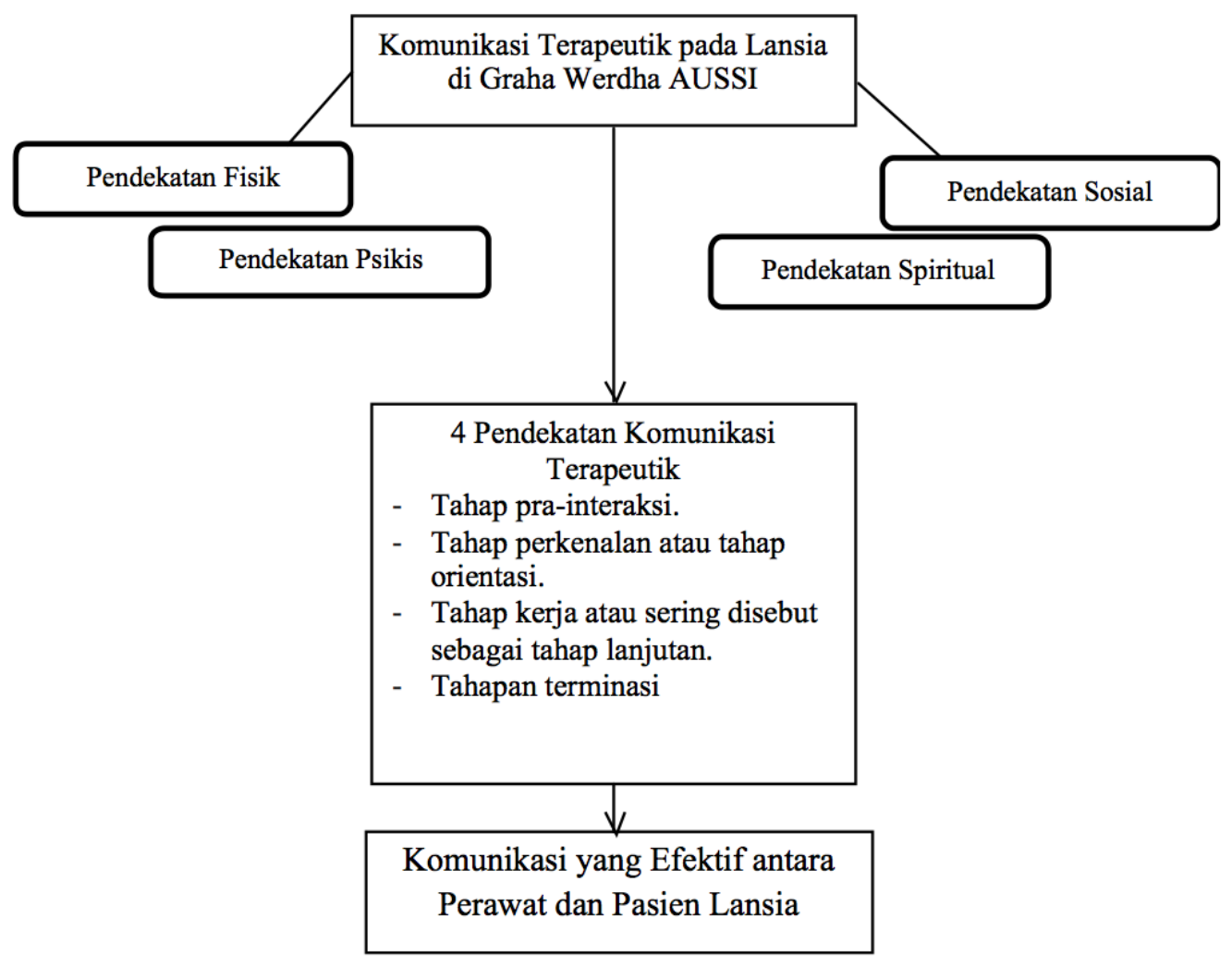

GAMBAR 3. Hasil Pembahasan

jenis kelamin, keluhan penyakit, dan sebagainya. Apabila perawat telah dapat mempersiapkan diri dengan baik sebelum bertemu dengan pasien, maka ia akan bisa menyesuaikan cara yang paling tepat dalam menyampaikan komunikasi terapeutik kepada pasien, sehingga pasien dapat dengan nyaman berkonsultasi dengan perawat. Dikarenakan di Graha Werdha AUSSI Kusuma Lestari, Depok mengharuskan 1 lansia ditangani oleh 1 perawat/suster, maka dapat dipastikan bahwa perawat yang menangani pasien lansia di Graha Werdha ini dapat dengan cepat dan akrab dengan para pasiennya.

(2) Tahap perkenalan atau tahap orientasi pada tahap ini antara perawat dan pasien lansia di Graha Werdha ini mempunyai kualitas yang cukup baik dalam hal kehangatan dan keterbukaan satu sama lain, seperti menceritakan tentang kondisi keluarganya saat ini, hobinya apa saja, cerita tentang masa mudanya dan lainnya sebagainya. Turn over para suster/ perawat di Graha Werdha ini pun dapat dikatakan cukup rendah, karena biasanya yang sulit yaitu adaptasi kembali kepada orang baru dalam hal ini, yaitu perawat/suster.

(3) Tahap kerja atau sering disebut sebagai tahap lanjutan adalah tahap pengenalan lebih jauh. Secara psikologis komunikasi yang bersifat terapeutik akan membuat pasien lebih tenang, dan tidak gelisah. Berdasarkan observasi di lapangan, penulis melihat bahwa perawat yang menangani pasien lansia di Graha Werdha ini dapat memberikan ketenangan dan mengurangi kecemasan bagi para pasiennya. Perawat/susternya hampir semuanya berpengalaman sehingga dapat menangani lansia dengan sangat baik dan sabar. 
Fitria Ayuningtyas dkk, Komunikasi Terapeutik pada Lansia di Graha Werdha...

TABEL 2. Pendekatan Keperawatan Lanjut Usia

\begin{tabular}{|c|c|c|}
\hline Pendekatan & $\begin{array}{c}\text { Bentuk Pendekatan } / \\
\text { Kegiatan }\end{array}$ & Keterangan \\
\hline Pendekatan Fisik & $\begin{array}{l}\text { Perawatan fisik secara umum } \\
\text { bagi pasien lanjut usia dapat } \\
\text { dibagi atas dua bagian, yakni } \\
\text { pasien lanjut usia yang masih } \\
\text { aktif dan pasif. }\end{array}$ & $\begin{array}{l}\text { Untuk mengetahui perubahan } \\
\text { fisik pada organ tubuh, } \\
\text { tingkat kesehatan yang } \\
\text { masih bisa dicapai dan } \\
\text { dikembangkan, dan penyakit } \\
\text { yang dapat dicegah atau } \\
\text { ditekan progresivitasnya bagi } \\
\text { pasien lansia. }\end{array}$ \\
\hline Pendekatan Psikis & $\begin{array}{l}\text { Mengadakan pendekatan } \\
\text { edukatif pada pasien lanjut } \\
\text { usia, perawat dapat berperan } \\
\text { sebagai supporter, interpreter } \\
\text { terhadap segala sesuatu yang } \\
\text { asing, dan sebagai sahabat } \\
\text { yang akrab. }\end{array}$ & $\begin{array}{l}\text { Untuk mendukung mental } \\
\text { pasien lansia ke arah } \\
\text { pemuasan pribadi sehingga } \\
\text { seluruh pengalaman yang } \\
\text { dilaluinya tidak menambah } \\
\text { beban, bila perlu diusahakan } \\
\text { agar di masa lanjut usia ini } \\
\text { mereka dapat merasa puas } \\
\text { dan bahagia. }\end{array}$ \\
\hline Pendekatan Sosial & $\begin{array}{l}\text { Mengadakan diskusi, tukar } \\
\text { pikiran, dan bercarita } \\
\text { merupakan salah satu upaya } \\
\text { perawat dalam pendekatan } \\
\text { sosial. Memberi kesempatan } \\
\text { untuk berkumpul bersama } \\
\text { dengan sesama klien lanjut } \\
\text { usia berarti menciptakan } \\
\text { sosialisasi mereka. }\end{array}$ & $\begin{array}{l}\text { Untuk mendukung } \\
\text { pasien lansia agar tetap } \\
\text { bersosialiasi dengan baik } \\
\text { dengan lingkungan di } \\
\text { sekitarnya, yaitu mengadakan } \\
\text { komunikasi dan melakukan } \\
\text { rekreasi, misalnya jalan pagi, } \\
\text { menonton film, atau hiburan- } \\
\text { hiburan lain serta selalu } \\
\text { dirangsang untuk mengetahui } \\
\text { dunia luar. }\end{array}$ \\
\hline Pendekatan Spiritual & $\begin{array}{l}\text { Perawat harus bisa memberikan } \\
\text { ketenangan dan kepuasan batin } \\
\text { dalam hubungannya dengan } \\
\text { Tuhan atau agama yang di } \\
\text { anutnya, terutama bila pasien } \\
\text { lanjut usia dalam keadaan sakit } \\
\text { atau mendekati kematian. }\end{array}$ & $\begin{array}{l}\text { Untuk memberikan } \\
\text { ketenangan kepada pasien } \\
\text { lansia, terutama ketika } \\
\text { menghadapi ketakutan } \\
\text { menghadapi kematian. }\end{array}$ \\
\hline
\end{tabular}

(4) Tahapan terminasi, pada tahap ini terjadi pengikatan antarpribadi yang lebih jauh. Pasien lansia di tahapan ini merasa pada akhirnya "cukup dekat" dengan para perawatnya, bahkan menganggap seperti keluarganya sendiri. Salah satunya seperti mengajak bicara dari hati ke hati antara perawat dan pasien lansia. 


\section{SIMPULAN}

Kesehatan yang optimal pada pasien lanjut usia atau selanjutnya penulis sebutsebagailansiatidakhanyabergantung kepada kebutuhan biomedis semata namun juga bergantung kepada kondisi disekitarnya, seperti perhatian yang lebih terhadap keadaan sosialnya, ekonominya, kulturalnya bahkan psikologisnya dari pasien tersebut. Hubungan saling memberi dan menerima antara perawat dan pasien dalam pelayanan keperawatan disebut sebagai komunikasi terapeutik perawat yang merupakan komunikasi profesional perawat. Komunikasi antara perawat dan pasien lansia harus berjalan efektif terutama bagi pasien lansia karena mempunyai pengaruh yang besar terhadap kesehatan dari pasien lansia tersebut. Komunikasi yang baik dengan pasien adalah kunci keberhasilan untuk masalah klinisnya. Komunikasi terapeutik merupakan komunikasi yang direncanakan secara sadar, bertujuan dan dipusatkan untuk kesembuhan pasien. Komunikasi terapeutik mengarah pada bentuk komunikasi interpersonal yaitu komunikasi antara orang-orang secara tatap muka yang memungkinkan setiap pesertanya menangkap reaksi orang lain sacara langsung, baik secara verbal dan nonverbal.

\section{DAFTAR PUSTAKA}

Ahmadi, Rulam. (2014). Metode Penelitian Kualitatif. Yogyakarta: Ar-Ruzz Media.

Cangara, Hafied. (2012). Pengantar Ilmu Komunikasi. Jakarta: PT Raja Grafindo Persada.

Cangara, Hafied. (2014). Perencanaan dan Strategi Komunikasi. Jakarta: PT Raja Grafindo Persada.

Central Intelligence Agency. (2010). www. cia.gov.

Crabtree, F. B., \& Miller, L.W. (1998). Doing Qualitative Research. Beverly Hills, CA: Sage

Creswell, John. W. (1998). Research design:
Qualitative, Quantitative, and Mixed Methods Approaches (2nd ed.). Thousand Oaks, CA: Sage.

Damaiyanti, Mukhripah. (2010). Komunikasi Terapeutik dalam Praktik Keperawatan. Bandung: Refika Aditama.

Departemen Kesehatan Indonesia. (2015). https://senyumperawat.com/2015/04/ pengertian-dan-klasifikasi-lansia.html diakses pada tanggal 7 September 2017.

Departemen Kesehatan Indonesia. (2017). Undang-Undang Republik Indonesia Nomor 44 Tahun 2009 tentang Rumah Sakit. http://www.depkes. go.id/resources/ download/peraturan/ UU\% 20 No.\% $2044 \% 20 \mathrm{Th} \% 20$ 2009\%20ttg\%20Rumah\%20Sakit. PDF diakses pada tanggal 7 September 2017.

Djaman, Evita. (2017). Alasan Menitipkan Orangtua Lansia ke Panti Jompo. https://cantik.tempo.co/read/ news/2017/03/07/336853455/alasanmenitipkan-orang-tua-lansia-ke-pantijompo diakses pada tanggal 3 Juni 2017.

Graha Werdha AUSSI Kusuma Lestari. (2017). https://www.facebook. com/pages/Graha-Werdha-AUSSIKusuma-Lestari/173111006128689

Kusuma, Shinta. (2017). Panti Werdha Pilihan Merawat Orang Tua. http:// www.pesona.co.id/article/pantiwerdha--pilihan-merawat-orangtua? $\mathrm{p}=3$ diakses pada tanggal 3 Juni 2017.

Maharani, Dian. (2014). Pasien Lansia Perlu Fasilitas Khusus di Rumah Sakit. http://lifestyle.kompas.com/ $\mathrm{read} / 2014 / 12 / 05 / 130000423 /$ Pasien. Lansia.Perlu.Fa silitas.Khusus. di.Rumah.Sakit diakses pada tanggal 7 September 2017.

Mufid, Muhammad. (2012). Etika Filsafat Komunikasi. Jakarta: Penerbit Kencana.

Mulyana, Deddy. (2009). Ilmu Komunikasi Suatu Pengantar. Bandung: Remaja 
Fitria Ayuningtyas dkk, Komunikasi Terapeutik pada Lansia di Graha Werdha...

Rosdakarya.

Mulyana, Deddy. (2005). Metodologi Penelitian Komunikasi. Bandung: Remaja Rosdakarya.

Moleong, Lexy. J. (2010). Metodologi Penelitian Kualitatif. Bandung: Remaja Rosdakarya.

Morissan. (2010). Psikologi Komunikasi. Bogor: Penerbit Ghalia Indonesia.

Perwari, Cendikia. (2015). Cara Perawatan Pada Lansia. http://www. perawatilmiah.com/2015/11/caraperawatan-pada-lansia.html diakses pada tanggal 7 September 2017.

Purwaningsih, W dan Karlina, I. (2012). Asuhan Keperawatan Jiwa. Yogyakarta: Nuha Medika.

Prasanti, Ditha. (2017). Komunikasi Terapeutik Tenaga Medis dalam Pemberian Informasi tentang Obat Tradisional bagi Masyarakat. Jurnal Mediator Vol. 10, no.1 tahun 2017. Sangadji dan Sopiah. (2013). Perilaku Konsumen - Pendekatan Praktis, Yogyakarta: Penerbit Andi. 